\title{
FRUIT QUALITY OF WILD, SWEET AND YELLOW PASSION FRUIT GENOTYPES IN DISTRITO FEDERAL, BRAZIL
}

\author{
Daiane da Silva NÓBREGA ${ }^{1}$ (D) , Ana Clara Nunes MENDES² iD, José Ricardo PEIXOTO ${ }^{\text {iD, }}$ \\ Michelle Souza VILELA ${ }^{2}$ (D) Fábio Gelape FALEIRO ${ }^{3}$ id Ernandes Rodrigues ALENCAR $^{2}$ iD, \\ Ricardo CARMONA² (iD, Rosa Maria de Deus SOUSA ${ }^{2}$ iD
}

\footnotetext{
${ }^{1}$ Postgraduate Program in Agronomy, University of Brasília, Brasília, Distrito Federal, Brazil.

2 Faculty of Agronomy and Veterinary Medicine, University of Brasília, Brasília, Distrito Federal, Brazil.

${ }^{3}$ Embrapa Cerrados, Planaltina, Brasília, Distrito Federal, Brazil.
}

\section{Corresponding author:}

Daiane da Silva Nóbrega

Email: daiane_nobrega@hotmail.com

How to cite: NÓBREGA, D.S., et al. Fruit quality of wild, sweet and yellow passion fruit genotypes in Distrito Federal, Brazil. Bioscience Journal. 2021, 37, e37064. https://doi.org/10.14393/BJ-v37n0a2021-48203

\begin{abstract}
Despite the importance of passion fruit for the Brazilian fruit market, there are still many agronomic and fruit quality problems to be solved, in order to increase this crop performance. The objective of this study was to evaluate the quality of twelve genotypes of wild, sweet and yellow passion fruit, aiming to identify promising materials considering fruit quality, in Federal District, Brazil. An experiment was carried out at the Água Limpa Farm of the Universidade de Brasília (UnB) from 2016 to 2018, in a randomized block design, with 12 treatments, 4 replicates and 6 plants/plot. At the harvesting time, six fruits per plot were randomly collected for the following physicochemical analysis: fruit mass, pulp mass with and without seeds, length/longitudinal diameter, width/transverse diameter, length/width ratio, husk thickness, predominant color of the pulp $\left(\mathrm{L}^{*}, \mathrm{C}^{*}, \mathrm{~h}^{*}\right)$, number of seeds, seed size, total soluble solids content, total titratable acidity, total soluble solids/total titratable acidity ratio and $\mathrm{pH}$. High heritability values and relation of genetic/environment variation coefficients ratio were observed for most of the characteristics evaluated. The genotypes of yellow passion fruit MAR20\#21 P2 x FB 200 P1 R2 and MAR20\#19 ROXO R4 x ECRAM P3 R3 showed the best characteristics of fruit mass and pulp mass with seed. All the genotypes studied showed values of total soluble solids above 11Brix. Positive and significant correlation was observed between fruit mass and length/width ratio, indicating that oblong fruits have higher fruit mass.
\end{abstract}

Keywords: Colorimetry. Genetic improvement. Passiflora spp. Physicochemical analyzis.

\section{Introduction}

Fruit industry is a growing activity in Brazil, generating jobs and income, which contributes to the development of fruit poles in the country. In this context, the importance of passion fruit is increasing in Brazil, despite some agronomic problems of this culture, such as low yields and fruits unevenness (Santos et al. 2017).

Several factors affect fruit quality in this species, including edaphoclimatic conditions, time of harvesting, genetic variability, cultural practices, maturation stage at harvesting, period of storage, temperature, storage packaging, among others. Some physicochemical properties of the fruits, which can vary among different genotypes, are important characteristics for the food and pharmaceutical passion fruit industries (Farias et al. 2007). 
During the maturation period, the yellow passion fruit undergoes through several physical and chemical changes, mainly due to the synthesis and the degradation of several substances. The main changes during maturation include the pectin degradation of the husk, color changes of the husk and changes in the fruit carbohydrates, organic acids, proteins, and lipids composition. The color change of the husk is the main criteria used to determine the best harvest time of the yellow passion fruit and reflects the physico-chemical changes which takes place during the fruit ripening process (Reolon et al. 2009).

The fruit characteristics are highly relevant, considering the consumption of in natura fruits, and the most appreciated fruits can be variable according to the consumption market preferences. These characteristics are mainly related to the flavor (total soluble solids and acidity) and juice content (yield). In addition, the external characteristics of the fruits should also meet certain standards to achieve the desired quality for the commercialization, such as color, shape, and size of the fruit (Cavichioli et al. 2011).

After harvesting, passion fruits are generally classified for consumption in natura or for industry. For in natura consumption, some physical characteristics, such as size, fruit shape, color of husk, color of fruit pulp and absence of defects are determinant elements of quality. In this way, fruits destined to the in natura consumption must be oval, weighing between 120 and $250 \mathrm{~g}$ of yellow-intense color and with orange pulp. Top quality fruits are remunerated at significantly higher prices (Gomes et al. 2006; Farias et al. 2007).

For industrialization, the fruit juice content should be above $40 \%$ of the total fruit weight, the flavor excellent, and the organic acid content and the total soluble solids (TSS) content should be high (higher than $15^{\circ}$ Brix). The relationship between total soluble solids content and total titratable acidity (TTA), called ratio, is one of the best ways to evaluate the flavor of the fruit. In addition, the high titre content of TTA decreases the need for addition of acidifiers and improves nutritional quality, food safety and organoleptic aspects (Farias et al. 2007; Raimundo et al. 2009).

The objective of this study was to estimate genetic parameters and evaluate characteristics related to fruit quality of twelve wild, sweet, and yellow passion fruit genotypes for the identification of promising materials and potential use in natura and/or by industry, under field conditions in Federal District, Brazil.

\section{Material and Methods}

The experiment was carried out in the field from October 2016 to August 2018, at the Água Limpa Experimental Farm (FAL) of the Universidade de Brasília (UnB), Brasília-DF, located at 16은 south latitude and 48 o west longitude, at 1,100 $\mathrm{m}$ above sea level. According to the classification of Köppen, the climate is Aw type in the Distrito Federal region, characterized as a tropical climate with dry season during winter and rainy season during summer (CARDOSO et al. 2014). During the experiment, some meteorological data were recorded daily from an automatic meteorological station located at FAL/UnB (UNB 2018).

The experiment comprised 12 treatments, 4 replications and 6 plants/plot, in a randomized block design, totalizing 48 plots and 288 plants. The plants were grown in vertical strings attached to 2 plain wires ( $\mathrm{n}-12$ ), at $1.60 \mathrm{~m}$ and $2.20 \mathrm{~m}$ above the soil, with $3 \mathrm{~m}$ distance between rows and $2 \mathrm{~m}$ between plants. The strings were tied up to $6 \mathrm{~m}$ distant poles. Four cultivars and eight genotypes, obtained from the passion fruit genetic breeding program of UnB and Embrapa, were tested (Table 1).

Table 1. Commercial cultivars ( 1 to 4 ) and genotypes from a breeding program of passion fruit of UnB in partnership with Embrapa (5 to 12). Brasília-DF, Brazil, 2019.

\section{CULTIVARS/GENOTYPES}
1. BRS Pérola do Cerrado (Passiflora setacea D.C.)
2. BRS Sertão Forte (Passiflora cincinnata Mast.)
3. BRS Mel do Cerrado (Passiflora alata Curtis)
4. BRS Gigante Amarelo (Passiflora edulis Sims)
5. CPAC MJ-02-17 - Progênie paterna do BRS Mel do Cerrado (Passiflora alata Curtis)
6. F1 MAR20\#44 R4 x ECL7 P2 R4 (Passiflora edulis Sims)
7. $F_{1}$ MAR20\#21 P2 x FB 200 P1 R2 (Passiflora edulis Sims)
8. F1 MAR20\#19 ROXO R4 $x$ ECRAM P3 R3 (Passiflora edulis Sims)
9. $F_{1}$ MAR20\#24 x ECL7 P1 R4 (Passiflora edulis Sims)
10. $F_{1}$ MAR20\#24 P1 R4 x ROSA CLARO P2 R4 (Passiflora edulis Sims)
11. $F_{1}$ MAR20\#100 R2 x MAR20\#21 R2 (Passiflora edulis Sims)
12. $F_{1}$ MAR20\#100 R2 x MAR20\#21 R1 (Passiflora edulis Sims) 
The fruits were harvested, in a weekly basis, at the total ripening stage, which means that the fruits were fallen in the soil after their natural abscission from the plant. Six fruits were randomly collected from each plot, totaling 24 fruits per genotype, to perform the physicochemical analyzes, which were carried out in the Laboratory of Bromatology of the UnB. The following characteristics were analyzed: fruit mass (g), pulp mass with and without seed (g), fruit length ( $\mathrm{mm}$ - longitudinal diameter), fruit width, length/width ratio $(\mathrm{mm})$, husk thickness, predominant color of the pulp, using a colorimeter ColorQuest XE - HunterLAb), number of seeds, seed size $(\mathrm{mm})$, total soluble solids content ( $\left.{ }^{\circ} \mathrm{Brix}\right)$, total titratable acidity (\% citric acid), SST/TTA ratio and $\mathrm{pH}$.

The physical analyzes were carried out individually in each fruit of the plot, resulting in six data of each characteristic per plot, which resulted in one average per characteristic per plot. For the chemical analyzes purposes, the fruit pulp was extracted with the aid of a food mixer and cooled to $5{ }^{\circ} \mathrm{C}$ to preserve the original characteristics. All physical analyzes were carried out based on the procedures described by the Ministério da Agricultura, Pecuária e Abastecimento (MAPA) with the Serviço Nacional de Proteção de Cultivares (SNPC-MAPA) and the methodology used by Embrapa (Jesus et al. 2015a; Jesus et al. 2015b; Jesus et al. 2016; Brasil 2016a; Brasil 2016b). The chemical analyzes were performed according to the analytical standards of the Instituto Adolfo Lutz (IAL 2008).

In addition, the characteristics related to the color of the fruit pulp were recorded according to the following color parameters: $L^{*}$ representing the luminosity; $C^{*}$ (chroma) representing the saturation of color and $\mathrm{h*}$ (hue angle) representing the variation between red and yellow (Ferreira and Spricigo 2013).

The data were submitted to the analysis of variance using the $\mathrm{F}$ test at the $5 \%$ probability level, the means were compared through Tukey test at $5 \%$ of probability; estimates of genetic parameters and Pearson correlation were also carried out using the software GENES (Cruz 1997). The linear correlation analyzes among all variables were performed based on the significance of their coefficients. The correlation intensity $(0.05 \leq p \geq 0.01)$ was classified as very strong ( $r \pm 0.91$ to \pm 1.00$)$, strong $(r \pm 0.71$ to \pm 0.90$)$, mean $(r \pm 0.51$ to \pm 0.70 ) and weak ( $r \pm 0.31$ to \pm 0.50 ), according to (Carvalho et al. 2004).

\section{Results}

The analysis of variance showed a significant difference between the cultivars/genotypes, at $5 \%$ of probability by the $\mathrm{F}$ test (Table 2), for the physical and chemical characteristics evaluated, except for the width (transverse diameter) of the fruits (LRG). Genetic variability was observed among the genotypes for the characteristics evaluated, favoring programs of genetic enhancement of these species. The coefficients of variation showed values below $30 \%$ for most of the characteristics evaluated, demonstrating good experimental accuracy.

The genetic parameters showed high heritability values $\left(h^{2}\right)$, ranging from $72.19 \%(C P(h *))$ to $94.87 \%$ (RATIO), demonstrating a favorable condition for selection (Table 2) (Vieira et al. 2005; Martins et al. 2014). In addition, the characteristics MF, MPCS, MPSS, CPT, R: C/L, EC, CC, CP (h*), SST, AZ, Ratio and pH showed $\mathrm{CVg} / \mathrm{CVe}$ values above 1 (Table 2) demonstrating that the environment had little influence on the phenotypic expression of these characteristics. The fruit width characteristic (LRG) showed low heritability value in the broad sense and $\mathrm{CVg} / \mathrm{CV}$ e ratio were lower than the unit (Table 2), which indicates higher effect of the environment in the formation of the phenotype.

Table 2. Summary of analysis of variance and estimation of genetic parameters for characteristics measured in wild, sweet and yellow passion fruit genotypes. Brasília-DF, Brazil, 2019.

\begin{tabular}{lcccccccc}
\hline & MF & MPCS & MPSS & CMP & LRG & R:C/L & EC & CC \\
\hline F & $6.84^{* *}$ & $6.29^{* *}$ & $7.04^{* *}$ & $17.85^{* *}$ & $2.00^{\text {NS }}$ & $11.67^{* *}$ & $7.34^{* *}$ & $7.34^{* *}$ \\
General average & 156.66 & 62.64 & 42.23 & 81.43 & 72.13 & 1.15 & 7.15 & 7.15 \\
CV (\%) & 20.67 & 25.57 & 26.75 & 8.15 & 19.98 & 6.25 & 18.06 & 18.06 \\
ha (\%) & 85.39 & 84.12 & 85.80 & 94.40 & 50.06 & 91.43 & 86.38 & 86.38 \\
CVg (\%) & 24.99 & 29.42 & 32.89 & 16.73 & 10.00 & 10.21 & 22.75 & 22.75 \\
CVe (\%) & 20.82 & 25.58 & 31.67 & 14.68 & 9.50 & 8.58 & 18.2 & 21.50 \\
CVg/ CVe & 1.20 & 1.15 & 1.22 & 2.05 & 0.50 & 1.63 & 1.25 & 1.25 \\
\hline
\end{tabular}

** Significant at $1 \%$ by F test. * Significant at $5 \%$ by F test. NS Not significant. Fruit mass - grams (MF); pulp mass with seeds - grams (MPCS); pulp mass without seeds - grams (MPSS); length/longitudinal diameter - mm (CMP); width/transverse diameter - mm 
(LRG); ratio: width/length - mm (R:C/L); husk thickness - mm (EC); husk color (CC); pulp color ( $\left.\mathrm{L}^{*}\right)$; pulp color ( $\left.\mathrm{C}^{*}\right)$; pulp color ( $\left.\mathrm{h}^{*}\right)$; number of seeds (NS); total soluble solids - ${ }^{\circ}$ Brix (SST); acidity - \% (AZ); ratio (SST/AZ) and hydrogenionic potential (pH).

Table 2 (continued). Summary of analysis of variance and estimation of genetic parameters for characteristics measured in wild, sweet and yellow passion fruit genotypes. Brasília-DF, Brazil, 2019.

\begin{tabular}{lllllllll}
\hline & $\mathrm{CP}\left(\mathrm{L}^{*}\right)$ & $\mathrm{CP}\left(\mathrm{C}^{*}\right)$ & $\mathrm{CP}\left(\mathrm{h}^{*}\right)$ & $\mathrm{NS}$ & $\mathrm{SST}$ & $\mathrm{AZ}$ & Ratio & $\mathrm{pH}$ \\
\hline $\mathrm{F}$ & $2.25^{*}$ & $2.88^{* *}$ & $11.38^{* *}$ & $4.47^{* *}$ & $8.99^{* *}$ & $19.25^{* *}$ & $19.50^{* *}$ & $15.94^{* *}$ \\
Média Geral & 44.43 & 16.43 & 64.00 & 247.73 & 13.67 & 4.40 & 4.27 & 2.73 \\
$\mathrm{CV}(\%)$ & 13.70 & 13.66 & 9.22 & 31.34 & 11.09 & 14.60 & 38.55 & 5.72 \\
$\mathrm{~h}^{2} \mathrm{a}(\%)$ & 55.72 & 65.32 & 72.19 & 77.63 & 88.88 & 94.80 & 94.87 & 93.72 \\
$\mathrm{CVg}(\%)$ & 7.68 & 9.37 & 14.85 & 29.20 & 15.67 & 31.19 & 82.91 & 11.05 \\
$\mathrm{CVe}(\%)$ & 13.71 & 13.77 & 9.22 & 31.39 & 11.11 & 14.64 & 38.56 & 5.72 \\
$\mathrm{CVg} / \mathrm{CVe}$ & 0.56 & 0.68 & 1.61 & 0.93 & 1.41 & 2.13 & 2.15 & 1.93 \\
\hline
\end{tabular}

** Significant at $1 \%$ by $\mathrm{F}$ test. * Significant at $5 \%$ by $\mathrm{F}$ test. ${ }^{N S}$ Not significant. Fruit mass - grams (MF); pulp mass with seeds - grams (MPCS); pulp mass without seeds - grams (MPSS); length/longitudinal diameter - mm (CMP); width/transverse diameter - mm (LRG); ratio: width/length - $\mathrm{mm}(\mathrm{R}: \mathrm{C} / \mathrm{L})$; husk thickness - $\mathrm{mm}(\mathrm{EC})$; husk color (CC); pulp color ( $\left.\mathrm{L}^{*}\right)$; pulp color ( $\left.\mathrm{C}^{*}\right)$; pulp color ( $\left.\mathrm{h}^{*}\right)$; number of seeds (NS); total soluble solids - ${ }^{\circ}$ Brix (SST); acidity - \% (AZ); ratio (SST/AZ) and hydrogenionic potential (pH).

Differences between means were observed using Tukey's Test at $5 \%$ of significance (Table 3 ) for most of the characteristics evaluated, except for seed size (TS). The comparative analyzes of the results were made between genotypes of the same species, because there is great variability in the evaluated genus. Considering the fruit mass characteristics (MF), the genotypes of passion fruit (Passiflora edulis Sims) were classified into four distinct groups, ranging from 101.25 grams (MAR20 \# 44 x ECL7 P2 R4) to 205.15 grams (cultivar Gigante Amarelo). The genotypes MAR20 \# 21 P2 x FB 200 P1 R2 (204.06 g) and MAR20\#19 ROXO R4 $x$ ECRAM P3 R3 (181.91 g) showed the highest MF values, which were statistically similar to the BRS Gigante Amarelo control (Table 3). These two genotypes, in addition to MAR20 \# 100 R2 x MAR20 \# 21 R2, also showed the highest results for pulp mass with seed (MPCS) among all of them (Table 3). In terms of pulp mass without seed (MPSS), the genotype MAR20 \# 21 P2 x FB 200 P1 R2 of the Passiflora edulis Sims species showed the highest average value (70.20 gr) among the yellow passion fruit species, being higher than the control cultivar BRS Gigante Amarelo. Among the sweet passion fruit species, the BRS Mel do Cerrado (Passiflora alata Curtis) obtained the highest value (37.75 gr) for MPSS, as well as the wild species BRS Sertão Forte (Passiflora cincinnata Mast.) (47.51 gr).

The highest results for length of fruits of Passiflora edulis Sims (CMP - longitudinal diameter) were observed on genotypes MAR20\#21 P2 x FB 200 P1 R1 (90.43 mm), MAR20\#100 R2 x MAR20 \# 21 R2 (85.37 $\mathrm{mm})$, MAR20\#19 ROXO R4 x ECRAM P3 R3 (84.90 mm), MAR20\#24 P1 R4 x ROSA CLARO P2 R4 (83.13 g), MAR20\#100 R2 $\times$ MAR20\#21 R1 $(82.54 \mathrm{~mm})$, all statistically similar to the cultivar BRS Gigante Amarelo control (93.61 mm) (Table 3). The yellow passion fruit genotypes showed similar LRG (transverse diameter) as the BRS Gigante Amarelo control (Table 3). Regarding the ratio: width/length (R: $C / L)$, the passion fruit genotypes reached values above 1 , indicating that the fruits are oval shaped (Table 3 ).

The best performance in terms of seed numbers (NS) (highest numbers) occurred in the following genotypes of yellow passion fruit: MAR20\#21 P2 x FB 200 P1 R2 (422.66 seeds) and MAR20\#100 R2 x MAR20\#21 R2 (285.54 seeds), similar statistically but superior numerically than BRS Gigante Amarelo control (275.42 seeds).

All yellow passion fruit genotypes showed thinner husk (EC) compared to BRS Gigante Amarelo control $(8.24 \mathrm{~mm})$. Among the studied materials, the genotypes MAR20\#100 R2 x MAR20\#21 R2 (6.42 mm), MAR20\#19 ROXO R4 x ECRAM P3 R3 $(6.70 \mathrm{~mm})$, MAR20\#21 P2 x FB 200 P1 R2 $(7.07 \mathrm{~mm})$ and MAR20\#24 P1 R4 x ROSA CLARO P2 R4 (7.13 mm) showed the thinnest husk layer (Table 3).

The fruit mass of Passiflora alata CPAC 02-17 MJ and BRS-Mel Cerrado were 160.88 and 195.06g, respectively, and the fruits are oval shaped $(R: C / L>1)$, but both genotypes did not show high values of MPSS and NS (18.26 g, 177.64 seeds and $37.75 \mathrm{~g}, 257.11$ seeds, respectively), which may be related to genetic, environmental and also pollination problems (Table 3).

The fruits of the genotype Passiflora cincinnata Mast. were round shaped $(R: C / L=0.96)$, with thin husk $(3.87 \mathrm{~mm}$ ) and mass of $118.74 \mathrm{~g}$. Machado et al. (2015) observed that $P$. cincinnata yielded a mean fruit mass value of $88.18 \mathrm{~g}$ and pulp yield of $35.39 \%$, lower than the values found in the present study. The 
genotype BRS Pérola cerrado (Passiflora setacea D.C.) showed slightly oval fruits $(R: C / L=1.10$ ), thin husk $(4.10 \mathrm{~mm})$, with $65.90 \mathrm{~g}$ of fruit weight, pulp mass without seeds of $22.24 \mathrm{gr}$ and 187,49 seeds per fruit.

Table 3. Test results of averages (Tukey 5\%) for characteristics measured in wild, sweet and yellow passion fruit genotypes. Brasília-DF, Brazil, 2019.

\begin{tabular}{lccccc}
\hline CULTIVARS/GENOTYPES & MF & MPCS & MPSS & NS & CMP \\
\hline MAR2O\#44 x ECL7 P2 R4 & $101.25^{\mathrm{cd}}$ & $33.61^{\mathrm{d}}$ & $24.11^{\mathrm{cde}}$ & $93.83^{\mathrm{c}}$ & $68.87^{\mathrm{cd}}$ \\
MAR20\#100 R2 x MAR20\#21 R2 & $170.77^{\mathrm{abc}}$ & $75.88^{\mathrm{ab}}$ & $47.49^{\mathrm{abcd}}$ & $285.54^{\mathrm{abc}}$ & $85.37^{\mathrm{b}}$ \\
MAR2O\#24 x ECL7 P1 R4 & $162.97^{\mathrm{abc}}$ & $55.79^{\mathrm{bcd}}$ & $37.77^{\mathrm{bcde}}$ & $248.54^{\mathrm{abc}}$ & $79.16^{\mathrm{bc}}$ \\
CPAC MJ-02-17 (Passiflora alata Curtis) & $160.88^{\mathrm{abc}}$ & $33.53^{\mathrm{d}}$ & $18.26^{\mathrm{e}}$ & $177.64^{\mathrm{bc}}$ & $87.62^{\mathrm{b}}$ \\
BRS Gigante Amarelo (Passiflora edulis Sims) & $205.15^{\mathrm{a}}$ & $74.22^{\mathrm{abc}}$ & $51.79^{\mathrm{abc}}$ & $275.42^{\mathrm{abc}}$ & $93.61^{\mathrm{ab}}$ \\
MAR2O\#19 ROXO R4 x ECRAM P3 R3 & $181.91^{\mathrm{ab}}$ & $77.61^{\mathrm{ab}}$ & $53.96^{\mathrm{ab}}$ & $260.04^{\mathrm{abc}}$ & $84.90^{\mathrm{bc}}$ \\
MAR20\#24 P1 R4 x ROSA CLARO P2 R4 & $160.74^{\mathrm{abc}}$ & $67.18^{\mathrm{abcd}}$ & $48.67^{\mathrm{abcd}}$ & $227.62^{\mathrm{bc}}$ & $83.13^{\mathrm{bc}}$ \\
MAR2O\#21 P2 x FB 200 P1 R2 & $204.06^{\mathrm{a}}$ & $96.27^{\mathrm{a}}$ & $70.20^{\mathrm{a}}$ & $422.66^{\mathrm{a}}$ & $90.43^{\mathrm{ab}}$ \\
BRS Mel do Cerrado (Passiflora alata Curtis) & $195.06^{\mathrm{ab}}$ & $58.65^{\mathrm{abcd}}$ & $37.75^{\mathrm{bcde}}$ & $257.11^{\mathrm{abc}}$ & $105.51^{\mathrm{a}}$ \\
BRS Pérola do Cerrado (Passiflora setacea D.C.) & $65.90^{\mathrm{d}}$ & $35.38^{\mathrm{cd}}$ & $22.24^{\mathrm{de}}$ & $187.49^{\mathrm{bc}}$ & $54.70^{\mathrm{d}}$ \\
BRS Sertão Forte (Passiflora cincinnata Mast.) & $118.74^{\mathrm{bcd}}$ & $78.74^{\mathrm{ab}}$ & $47.51^{\mathrm{abcd}}$ & $330.22^{\mathrm{ab}}$ & $61.27^{\mathrm{b}}$ \\
MAR20\#100 R2 x MAR20\#21 R1 & $152.45^{\mathrm{abc}}$ & $64.87^{\mathrm{abcd}}$ & $47.09^{\mathrm{abcd}}$ & $206.66^{\mathrm{bc}}$ & $82.54^{\mathrm{bc}}$ \\
\hline
\end{tabular}

Means followed by the same letter do not differ from each other, by the Tukey test at $5 \%$ probability. Legend: Fruit mass - grams (MF), pulp mass with seeds - grams (MPCS), mass of the pulp without seeds - grams (MPSS), seed number - (NS), length/longitudinal diameter - grams (CMP), width/transverse diameter - millimeters (LRG) Width/Length - mm (R:C/L), hull thickness - mm (EC), shell color (CC), pulp color $\left(\mathrm{L}^{*}\right)$, pulp color $\left(\mathrm{C}^{*}\right)$, pulp color $\left(\mathrm{h}^{*}\right)$, total soluble solids - ${ }^{\circ}$ Brix (SST), acidity - \% $(\mathrm{AZ})$, ratio (SST/AZ) and hydrogenation potential $(\mathrm{pH})$.

Table 3 (continued). Test results of averages (Tukey 5\%) for characteristics measured in wild, sweet and yellow passion fruit genotypes. Brasília-DF, Brazil, 2019.

\begin{tabular}{lccccc}
\hline CULTIVARS/GENOTYPES & LRG & R:C/L & EC & CC & $C P\left(L^{*}\right)$ \\
\hline MAR2O\#44 x ECL7 P2 R4 & $93.45^{\mathrm{a}}$ & $0.98^{\mathrm{cd}}$ & $7.63^{\mathrm{a}}$ & $3.00^{\mathrm{b}}$ & $42.27^{\mathrm{ab}}$ \\
MAR20\#100 R2 x MAR2O\#21 R2 & $75.78^{\mathrm{ab}}$ & $1.13^{\mathrm{bcd}}$ & $6.42^{\mathrm{abc}}$ & $1.00^{\mathrm{c}}$ & $39.00^{\mathrm{b}}$ \\
MAR2O\#24 x ECL7 P1 R4 & $72.10^{\mathrm{ab}}$ & $1.10^{\mathrm{bcd}}$ & $8.20^{\mathrm{a}}$ & $4.00^{\mathrm{a}}$ & $44.80^{\mathrm{ab}}$ \\
CPAC MJ-02-17 (Passiflora alata Curtis) & $71.99^{\mathrm{ab}}$ & $1.22^{\mathrm{b}}$ & $9.35^{\mathrm{a}}$ & $3.00^{\mathrm{b}}$ & $42.49^{\mathrm{ab}}$ \\
BRS Gigante Amarelo (Passiflora edulis Sims) & $76.41^{\mathrm{ab}}$ & $1.22^{\mathrm{b}}$ & $8.24^{\mathrm{a}}$ & $1.00^{\mathrm{c}}$ & $40.64^{\mathrm{ab}}$ \\
MAR2O\#19 ROXO R4 x ECRAM P3 R3 & $71.14^{\mathrm{ab}}$ & $1.19^{\mathrm{b}}$ & $6.70^{\mathrm{abc}}$ & $1.00^{\mathrm{c}}$ & $43.39^{\mathrm{ab}}$ \\
MAR20\#24 P1 R4 x ROSA CLARO P2 R4 & $71.76^{\mathrm{ab}}$ & $1.16^{\mathrm{b}}$ & $7.13^{\mathrm{ab}}$ & $1.00^{\mathrm{c}}$ & $45.14^{\mathrm{ab}}$ \\
MAR20\#21 P2 x FB 200 P1 R2 & $76.56^{\mathrm{ab}}$ & $1.18^{\mathrm{b}}$ & $7.07^{\mathrm{abc}}$ & $1.00^{\mathrm{c}}$ & $39.13^{\mathrm{b}}$ \\
BRS Mel do Cerrado (Passiflora alata Curtis) & $73.07^{\mathrm{ab}}$ & $1.44^{\mathrm{a}}$ & $9.47^{\mathrm{a}}$ & $3.00^{\mathrm{b}}$ & $47.88^{\mathrm{ab}}$ \\
BRS Pérola do Cerrado (Passiflora setacea D.C.) & $48.40^{\mathrm{b}}$ & $1.10^{\mathrm{bcd}}$ & $4.10^{\mathrm{bc}}$ & $1.00^{\mathrm{c}}$ & $55.00^{\mathrm{a}}$ \\
BRS Sertão Forte (Passiflora cincinnata Mast.) & $63.56^{\mathrm{ab}}$ & $0.96^{\mathrm{a}}$ & $3.87^{\mathrm{c}}$ & $1.00^{\mathrm{c}}$ & $49.39^{\mathrm{ab}}$ \\
MAR20\#100 R2 x MAR2O\#21 R1 & $71.36^{\mathrm{ab}}$ & $1.16^{\mathrm{bc}}$ & $7.60^{\mathrm{a}}$ & $1.00^{\mathrm{c}}$ & $44.07^{\mathrm{ab}}$ \\
\hline
\end{tabular}

Means followed by the same letter do not differ from each other, by the Tukey test at $5 \%$ probability. Legend: Fruit mass - grams (MF), pulp mass with seeds - grams (MPCS), mass of the pulp without seeds - grams (MPSS), seed number - (NS), length/longitudinal diameter - grams (CMP), width/transverse diameter - millimeters (LRG) Width/Length - mm (R:C/L), hull thickness - mm (EC), shell color (CC), pulp color $\left(\mathrm{L}^{*}\right)$, pulp color $\left(\mathrm{C}^{*}\right)$, pulp color $\left(\mathrm{h}^{*}\right)$, total soluble solids - ${ }^{\circ}$ Brix (SST), acidity - \% (AZ), ratio (SST/AZ) and hydrogenation potential $(\mathrm{pH})$.

Table 3 (continued). Test results of averages (Tukey 5\%) for characteristics measured in wild, sweet and yellow passion fruit genotypes. Brasília-DF, Brazil, 2019.

\begin{tabular}{|c|c|c|c|c|c|c|}
\hline CULTIVARS/GENOTYPES & $\mathrm{CP}\left(\mathrm{C}^{*}\right)$ & $\mathrm{CP}\left(\mathrm{h}^{*}\right)$ & SST & $\mathrm{AZ}$ & Ratio & $\mathrm{pH}$ \\
\hline MAR20\#44 x ECL7 P2 R4 & $16.91^{\mathrm{ab}}$ & $55.24^{c}$ & $14.22^{\mathrm{bc}}$ & $5.71^{\mathrm{a}}$ & $2.49^{b}$ & $2.60^{b}$ \\
\hline MAR20\#100 R2 x MAR20\#21 R2 & $17.49^{a b}$ & $58.61^{\mathrm{c}}$ & $12.64^{\mathrm{bc}}$ & $5.36^{a}$ & $2.38^{\mathrm{b}}$ & $2.57^{b}$ \\
\hline MAR20\#24 x ECL7 P1 R4 & $16.94^{\mathrm{ab}}$ & $60.33^{c}$ & $13.17^{b c}$ & $4.99^{a}$ & $2.64^{b}$ & $2.60^{b}$ \\
\hline CPAC MJ-02-17 (Passiflora alata Curtis) & $18.86^{\mathrm{a}}$ & $63.67^{b c}$ & $16.11^{\mathrm{ab}}$ & $2.04^{b}$ & $11.22^{\mathrm{a}}$ & $3.27^{\mathrm{a}}$ \\
\hline BRS Gigante Amarelo (Passiflora edulis Sims) & $15.89^{a b}$ & $61.58^{c}$ & $13.30^{\mathrm{bc}}$ & $4.63^{a}$ & $2.92^{\mathrm{b}}$ & $2.67^{b}$ \\
\hline MAR20\#19 ROXO R4 x ECRAM P3 R3 & $14.52^{\mathrm{ab}}$ & $58.91^{\mathrm{c}}$ & $11.34^{\mathrm{c}}$ & $4.90^{a}$ & $2.30^{\mathrm{b}}$ & $2.55^{b}$ \\
\hline MAR20\#24 P1 R4 x ROSA CLARO P2 R4 & $16.62^{\mathrm{ab}}$ & $63.14^{\mathrm{bc}}$ & $13.87^{\mathrm{bc}}$ & $5.30^{\mathrm{a}}$ & $2.62^{\mathrm{b}}$ & $2.52^{b}$ \\
\hline MAR20\#21 P2 x FB 200 P1 R2 & $16.05^{\mathrm{ab}}$ & $63.64^{b c}$ & $11.82^{c}$ & $4.94^{a}$ & $2.40^{\mathrm{b}}$ & $2.62^{b}$ \\
\hline BRS Mel do Cerrado (Passiflora alata Curtis) & $15.13^{\mathrm{ab}}$ & $64.20^{\mathrm{bc}}$ & $18.46^{a}$ & $1.49^{b}$ & $12.41^{\mathrm{a}}$ & $3.50^{\mathrm{a}}$ \\
\hline BRS Pérola do Cerrado (Passiflora setacea D. C.) & $19.47^{\mathrm{a}}$ & $77.70^{\mathrm{ab}}$ & $16.32^{\mathrm{ab}}$ & $2.98^{b}$ & $5.53^{b}$ & $2.65^{b}$ \\
\hline BRS Sertão Forte (Passiflora cincinnata Mast.) & $12.30^{\mathrm{b}}$ & $88.77^{a}$ & $11.42^{c}$ & $5.42^{a}$ & $2.16^{b}$ & $2.66^{b}$ \\
\hline MAR20\#100 R2 x MAR20\#21 R1 & $17.06^{\mathrm{ab}}$ & $52.27^{c}$ & $11.39^{c}$ & $5.09^{a}$ & $2.25^{b}$ & $2.56^{b}$ \\
\hline
\end{tabular}


Means followed by the same letter do not differ from each other, by the Tukey test at 5\% probability. Legend: Fruit mass - grams (MF), pulp mass with seeds - grams (MPCS), mass of the pulp without seeds - grams (MPSS), seed number - (NS), length/longitudinal diameter - grams (CMP), width/transverse diameter - millimeters (LRG) Width/Length - mm (R:C/L), hull thickness - mm (EC), shell color (CC), pulp color $\left(L^{*}\right)$, pulp color $\left(C^{*}\right)$, pulp color $\left(h^{*}\right)$, total soluble solids - ${ }^{\circ}$ Brix $(S S T)$, acidity - \% $(A Z)$, ratio (SST/AZ) and hydrogenation potential $(\mathrm{pH})$.

The fruits of passion fruit yellow evaluated in the present work showed colorations between yellow and light orange, according to classification standards of pulp coloration of the Ministério da Agricultura, Pecuária e Abastecimento - MAPA (Brasil 2016a). The wild ones showed pulp coloration ranging from yellowgreen, for the cultivars BRS Pérola do Cerrado and BRS Sertão Forte, to yellow-orange for the others.

The color of the fruit pulp was also measured using a colorimeter (ColorQuest XE colorimeter tristimulus - HunterLab). The values of the $L$ * parameter for the genotypes ranged from 39.00 (MAR20\#100 R2 \# x MAR20\#21 R2) to 49.39 (BRS Sertão Forte (Passiflora cincinnata Mast.)). In the analyzed materials, the highest $\mathrm{h}$ value was observed in cultivar BRS Sertão Forte (Passiflora cincinnata Mast.) (88,77; Table 3), which differed from the other genotypes evaluated, except from BRS Pérola do Cerrado, indicating a color closer to yellow. The other materials showed lower $h$ values, tending to a color between red and yellow, closer to the orange (Shewfelt et al. 1988; Mcguire 1992). The C* values ranged from 12.30 to 18.86 (Table 3).

All wild, sweet and yellow passion fruit genotypes tested reached soluble solids (SST) above the minimum required $\left(11^{\circ} \mathrm{Brix}\right)$ for the production of passion fruit pulp (Passiflora edulis Sims), according to the identity and quality standards of the Ministério da Agricultura, Pecuária e Abastecimento (MAPA) (Table 3) (Brasil 2018).

The fruits of the genotypes CPAC MJ-02-17 and BRS Mel do Cerrado (Passiflora alata Curtis) reached values of soluble solids ( ${ }^{\circ} \mathrm{Brix}$ ) and titratable acidity of 16.11 and $18.46^{\circ} \mathrm{Brix}, 2.04$ and $1.42 \%$, respectively (Table 3). These values are similar to those observed by Alves et al. (2012), as values of soluble solids ( ${ }^{\circ} \mathrm{Brix}$ ) and titratable acidity (\% citric acid) were $18.20 \pm 1.43^{\circ}$ Brix and $1.20 \pm 0.25 \%$, respectively.

In the present work, the genotypes of Passiflora edulis Sims, Passiflora cincinnata Mast. and Passiflora setacea DC contained acid values above that required by MAPA, except for Passiflora alata Curtis species, since they are all destined for in natura consumption (Table 3). The acidity of the yellow passion fruit genotypes was similar to that observed for the BRS Gigante Amarelo control, ranging from $4.63 \%$ to $5.71 \%$, which makes it possible to classify the genotypes for both in natura and industry uses. The genotype of the species Passiflora setacea D. C. (2.98\%) can be used for in natura consumption and Passiflora cincinnata Mast. (5.42\%) for industrial purposes (Table 3).

In the present study, the species of Passiflora setacea D. C. (BRS Pérola do Cerrado) showed a ratio of 5.53, higher than the values recommended in the literature. The genotypes of Passiflora edulis Sims reached lower values, ranging from 2.16 to 2.92 and Passiflora cincinnata Mast. (BRS Sertão Forte) of 2.16 (Table 3).

In this study too, the fruits of the species Passiflora alata Curtis showed $\mathrm{pH}$ values above those determined by the Normative no37 of the MAPA (Brasil 2018): CPAC MJ-02-17 - pH = 3.27 and BRS Mel do Cerrado $-\mathrm{pH}=3.70$ (Table 3).

The analysis of linear correlation (Pearson) showed strong positive and significant correlations between MPSS and MPCS, CMP and MF, CMP and R:C/L, CMP and EC, NS and MPCS, NS and MPSS, $\mathrm{pH}$ and SST, pH and RATIO, RATIO and SST. Negative correlations occurred between $C P\left(L^{*}\right)$ and $L R G, A Z$ and $p H, A Z$ and SST, AZ and RATIO variables (Table 4). 
Table 4. Pearson correlation coefficient values for characteristics measured in wild, sweet and yellow passion fruit genotypes. Brasília-DF, 2019.

\begin{tabular}{|c|c|c|c|c|c|c|c|c|c|c|c|c|c|c|c|c|}
\hline & $\mathrm{MF}$ & MPCS & MPSS & $\mathrm{CMP}$ & LRG & $\mathrm{R}: \mathrm{C} / \mathrm{L}$ & EC & SST & Ratio & NS & TS & $\mathrm{pH}$ & $C P\left(L^{*}\right)$ & $\mathrm{CP}\left(\mathrm{C}^{*}\right)$ & $\mathrm{CP}(\mathrm{h} *)$ & $A Z$ \\
\hline $\mathrm{MF}$ & 1 & $0.62 *$ & $0.64^{*}$ & $0.91 * *$ & 0.37 & $0.66^{*}$ & $-0.61 *$ & -0.15 & 0.09 & 0.56 & 0.05 & -0.22 & $-0.67 *$ & -0.29 & -0.43 & -0.05 \\
\hline MPCS & - & 1 & $0.97 * *$ & 0.34 & 0.05 & 0.10 & -0.17 & $-0.65^{*}$ & -0.47 & $0.88^{* *}$ & -0.44 & -0.33 & -0.40 & $-0.62^{*}$ & 0.04 & 0.44 \\
\hline MPSS & - & - & 1 & 0.36 & 0.12 & 0.12 & -0.10 & $-0.66 *$ & -0.53 & $0.82^{* *}$ & -0.49 & -0.40 & -0.44 & -0.55 & -0.08 & 0.49 \\
\hline CMP & - & - & - & 1 & 0.42 & $0.85^{* *}$ & $0.80^{* *}$ & 0.18 & 0.39 & 0.29 & 0.17 & 0.49 & -0.57 & -0.11 & -0.54 & -0.31 \\
\hline LRG & - & - & - & - & 1 & -0.00 & $0.58^{*}$ & -0.14 & -0.14 & -0.16 & 0.03 & -0.01 & $-0.76 * *$ & -0.12 & $-0.66^{*}$ & 0.35 \\
\hline $\mathrm{R}: \mathrm{C} / \mathrm{L}$ & - & - & - & - & - & 1 & $0.65^{*}$ & 0.51 & $0.66^{*}$ & 0.16 & 0.17 & $0.68^{*}$ & -0.10 & 0.05 & -0.30 & $-0.68 *$ \\
\hline EC & - & - & - & - & - & - & 1 & 0.36 & 0.49 & -0.20 & 0.42 & 0.54 & -0.50 & 0.19 & $-0.69 *$ & -0.37 \\
\hline SST & - & - & - & - & - & - & - & 1 & $0.86 * *$ & -0.42 & 0.34 & $0.77^{* *}$ & 0.41 & 0.41 & 0.09 & $-0.84 * *$ \\
\hline Ratio & - & - & - & - & - & - & - & - & 1 & -0.22 & $0.61^{*}$ & $0.96 * *$ & 0.25 & 0.24 & 0.08 & $-0.95 * *$ \\
\hline NS & - & - & - & - & - & - & - & - & - & 1 & -0.26 & -0.10 & -0.23 & -0.50 & 0.29 & 0.16 \\
\hline TS & - & - & - & - & - & - & - & - & - & - & 1 & 0.56 & -0.15 & 0.37 & -0.03 & -0.52 \\
\hline $\mathrm{pH}$ & - & - & - & - & - & - & - & - & - & - & - & 1 & 0.15 & 0.04 & 0.08 & $-0.89 * *$ \\
\hline $\mathrm{CP}\left(\mathrm{L}^{*}\right)$ & - & - & - & - & - & - & - & - & - & - & - & - & 1 & 0.01 & $0.67^{*}$ & -0.38 \\
\hline $\mathrm{CP}\left(\mathrm{C}^{*}\right)$ & - & - & - & - & - & - & - & - & - & - & - & - & - & 1 & -0.33 & -0.31 \\
\hline $\mathrm{CP}\left(\mathrm{h}^{*}\right)$ & - & - & - & - & - & - & - & - & - & - & - & - & - & - & 1 & -0.16 \\
\hline$A Z$ & - & - & - & - & - & - & - & - & - & - & - & - & - & - & - & 1 \\
\hline
\end{tabular}

Fruit mass - grams (MF), pulp mass with seeds - grams (MPCS), mass of the pulp without seeds - grams (MPSS), length/longitudinal diameter grams (CMP), width/transverse diameter - millimeters (LRG), Width/Length - $\mathrm{mm}(\mathrm{R}: \mathrm{C} / \mathrm{L})$, hull thickness - mm (EC), total soluble solids - $\left({ }^{\circ} \mathrm{Brix}\right)$, ratio (SST/AZ), number of seeds - unit (NS), seed size - millimeters (TS), hydrogen ionic potential ( $\mathrm{pH})$, pulp color ( $\left.\mathrm{L}^{*}\right)$, color pulp (C*), color pulp $\left(h^{*}\right)$, acidity - \% (AZ).

The Pearson correlation analysis, which showed that the mean number of seeds per fruit has a mean correlation with the variables mean fruit mass and pulp yield. In the present study, a strong and positive phenotypic correlation was also observed between NS and MPCS ( $\mathrm{rf}=0.88), \mathrm{NS}$ and MPSS ( $\mathrm{rf}=0.82)$, and a very strong and positive one between MPSS and MPCS ( $\mathrm{ff}=0.97)$ (Table 4). Therefore, it is possible to observe that some genotypes that showed higher mean values of NS also had the highest values of MPCS and MPSS (BRS Gigante Amarelo and hybrid MAR20\#100 R2 x MAR20\#21 R2, MAR20\#21 P2 x FB 200 P1 R2, MAR20\#19 ROXO R4 x ECRAM P3 R3 - Table 3).

There was a positive and very strong correlation between CMP and MF ( $r f=0.91$ ), suggesting that higher longitudinal length fruits also present higher mass. Fruit mass also correlated positively with the R:C/L ratio ( $r f=0.66$ ), demonstrating that oblong fruit tend to have higher fruit mass. In the studied genotypes, there was a very strong correlation between $A Z$ and RATIO ( $r f=-0.95)$ and a strong correlation between AZ and $\mathrm{pH}(\mathrm{rf}=-0.89), \mathrm{AZ}$ and SST $(\mathrm{rf}=-0.84)$.

\section{Discussion}

Based on the analysis of variance, simple genetic enhancement programs (mass selection) are likely to present good results, since the phenotype of the evaluated characteristics will not have a significant influence on the environmental variation (Chagas et al. 2016). The fruit width characteristic (LRG) would be recommended to work on improving characteristics that behave in this way, it would be necessary to use more elaborated breeding methods, not just the mass selection one.

In the development of a variety for the in natura market, there is always concern in selecting larger and oval fruits, because they normally have better commercial acceptance and higher juice yields, characteristics important mainly for the fruits aiming the industry. The shape of the fruit is associated with the relationship between fruit length and diameter, in which values above 1 indicate oval or oblong fruits and values equal to or less than 1 indicate round fruits. In passion fruit, the ideal is to select oval fruits for obtaining higher juice yields and higher commercial values (Negreiros et al. 2008; Aguiar et al. 2015). Therefore, the genotypes studied in the present work showed suitable characteristics considering quality standards.

Santos et al. (2017), studying the production and quality of yellow passion fruit, observed values for fruit mass ranging from $93.50 \mathrm{~g}$ to $201.75 \mathrm{~g}$, length from 72.5 to $85.0 \mathrm{~mm}$, width from 60.0 to $72.5 \mathrm{~mm}$ and R: C/L from 1.00 to 1.27. Chagas et al. (2016), evaluating fruit quality of two populations of Passiflora edulis Sims by means of physical and chemical characteristics analyzes, observed fruits mass ranging from 150.21 $\mathrm{g}$ to $305.52 \mathrm{~g}$, length from 73.59 to $107.42 \mathrm{~mm}$, width from 76.80 to $99.42 \mathrm{~mm}$ and R: C/L from 1.00 to 1.27 . Greco et al. (2014), studying fruit quality of yellow passion fruit genotypes, verified average fruit mass values 
ranging from $128.75 \mathrm{gr}$ to $207.83 \mathrm{gr}$ and pulp mass ranging from $44.68 \mathrm{gr}$ to $94.30 \mathrm{gr}$, which were similar to those observed in the present study. Similar results were also observed for other characteristics such as MF, MPCS, CMP, LRG and R: C/L.

The number of seeds is related to the yield of pulp, since the pulp is adhered to the seeds and, consequently, fruits with higher number of seeds usually have higher yields of juice (Santos et al. 2017). Fruits with thick husk are undesirable, once the commercial part of the fruit is the juice (Santos et al. 2017).

Similar results for Passiflora alata Curtis were observed by Alves et al. (2012) for the relationships between physical and chemical characteristics of sweet passion fruit, in which the fresh matter mass of the fruits showed a mean of $194.53 \pm 42.19 \mathrm{~g}$, the fresh matter mass of the pulp $43.75 \pm 10.98 \mathrm{~g}$, the length $85.35 \pm 5.83 \mathrm{~mm}$, width $74.59 \pm 5.07 \mathrm{~mm}$, husk thickness $9.92 \pm 2.04 \mathrm{~mm}$, number of seeds $268.73 \pm 50.68$ and percentage of pulp $23.30 \pm 6.82 \%$. Alves et al. (2012) also observed that the fruit diameter showed a positive correlation with the mass of the fresh matter of the pulp and a negative one with the percentage of pulp, indicating that larger fruits have, proportionally, less pulp than the smaller ones. There was also a negative correlation between the thickness and mass of the fresh matter of the husk and the percentage of pulp, indicating that the thicker husk reduces the diameter of the internal cavity of the fruit, where the edible pulp accumulates.

The color of the fruit pulp is also an important characteristic for the passion fruit juice industry. According to Brasil (2016a), the pulp of the passion fruit may vary from whitish, yellow-green, yellow, lightorange and dark-orange. For the wild fruits (Brasil 2016b), the pulp color is composed of whitish, yellowishgreen, yellow, orange-yellow, orange-dark, red and purple.

According to Pathare et al. (2013), when reading the fruit pulp color measured in a colorimeter, the values of $L *$ represent the variation between white (100) and black (0), that is, refers to luminosity. Thus, larger $L *$ values indicate lighter pulps, and higher values, darker pulps. The $h$, represents hue angle, a variation between red and yellow, following a scale from 0 to 90 . The $\mathrm{C}^{*}$, chroma, is related to color saturation, and the higher its value, the higher the concentration of the coloring element.

As for the content of SST indicates the maturity and quality standard of the raw material used by the juice and derivative industries, that is, the higher the amount of TSS, the higher the sugar content, an important characteristic in the agroindustrial process. During fruit ripening, some transformations takes place in the characteristics of the fruits, such as the accumulation of sugars (glucose, fructose and sucrose) and the simultaneous reduction of the acidity. The sugar content reaches the maximum at the end of the ripening process, conferring excellence to the quality of the product. The high content of soluble solids allows the use of a smaller amount of pulp to elaborate the concentrated juice and the high acidity guarantees greater flexibility in the addition of sugars (Neto et al. 2015).

Different fruit standards are demanded by the industry of passion fruit juices, as the SST content of 11.4 and $18^{\circ} \mathrm{Brix}$, TTA of 2.7 to 3.9 (g of citric acid $100 \mathrm{~mL}-1$ ) and SST/AAT ratio of 3.5 to 4.7 (Machado et al. 2015; Neto et al. 2015; Silva et al. 2016). The large amplitude in the SST contents observed in the present study can be atributed to the variability in the genus Passiflora (Chagas et al. 2016).

According to previous studies (Machado et al. 2015; Coelho et al. 2016) the fruits of passion fruit (Passiflora alata Curtis) have sweet-sour taste pulp, pleasant aroma, low acidity, lower yield than the yellow passion fruit, usually consumed in natura, not being used in juices processing to present high soluble solids content, which can make the drink sickening. The Passiflora alata Curtis is shown as an option to occupy not only the domestic market, but also the external market, especially the European one, as the second most important brazilian exportation fruit juice (Machado et al. 2015; Coelho et al. 2016).

Silva et al. (2016) reported that the high levels of organic acids (acidity) in passion fruit juice are interesting for fruits destined to the industry, while the low acidity is desirable for fruits destined to the in natura market. The high acidity of the juice is an important characteristic in the fruit processing, allowing to reduce the use of artificial acidifiers, considering that acidity is an important parameter in the conservation of food products (Neto et al. 2015). According to the quality and identity standards required by MAPA, passion fruit pulp must contain at least $2.5 \%(2.5 \mathrm{~g} / 100 \mathrm{~g})$ of total acidity, expressed as citric acid (Silva et al. 2016).

According to Silva et al. (2016) the yellow passion fruit destined to the in natura and industry market must have titratable acidity between $2.9 \%$ and $5.0 \%$. Machado et al. (2015), studying the genetic divergence 
among different species of passion fruit, observed titratable acidity values of $4.23 \%$ of citric acid in $100 \mathrm{~mL}$ of juice in $P$. cincinnata.

The SST/TTA ratio is an important chemical characteristic to evaluate the quality of passion fruit, because it is related to the fruit flavor, that results of the contribution of the components responsible for the acidity and sweetness, which may contribute to a better palatability to the pulp. The SST/TTA ratio is more representative for the palatability than the SST or TTA measurement alone. In general, the higher the value of this ratio, the more palatable is the juice or fruit pulp, since the total soluble solids content is high and / or the acidity is low. In addition, values of SST/TTA between 3.4 and 4.5 indicate fruit with adequate quality, both for the in natura consumption or for fruit processing (Greco et al. 2014; Silva et al. 2016; Santos et al. 2017).

Machado et al. (2015) observed that the species P. setacea (BGP 357) had expressive values of soluble solids (16.45 -Brix) and ratio (SST/AAT) of 8.08. Greco et al. (2014) also found similar values, ranging from 2.12 to 3.02 in the species of yellow passion fruit (Passiflora edulis Sims).

The $\mathrm{pH}$ is used to indirectly determine fruit acidity. The variation of $\mathrm{pH}$ is not only associated with acidity since the $\mathrm{pH}$ depends both on the concentration of free $\mathrm{H}^{+}$ions and on the buffering capacity of the juice or the pulp (Silva et al. 2016). According to Normative Instruction no 37 of MAPA, passion fruit juice (Passiflora spp.) must contain a minimum pH of 2.7 (Brazil 2018). In the literature there are also several reports stating that fruits with low $\mathrm{pH}$ can be used for in natura consumption. Chagas et al. (2016), studying the physical and chemical characteristics of fruits of two populations of passion fruit, observed $\mathrm{pH}$ values ranging from 2.35 to 2.62, similar to the genotypes studied in the present study (Table 2). Neto et al. (2015) also observed pH values between 2.52 and 2.96 and Greco et al. (2014) from 2.42 to 3.80, in their respective studies.

Fortaleza et al. (2005) observed that the fruit mass is usually proportional to the number of viable seeds, and consequently also proportional to the yield of juice in the passion fruit crop, interesting characteristics both for fresh fruits and for industrialization.

In addition, Fortaleza et al. (2005) states that the relationship between the length and diameter of passion fruit is used to evaluate the shape of the fruit. This characteristic is important for industry, since there is a preference for oblong fruits because they present about $10 \%$ more than juice than the round ones. Thus, fruits of longer length (oblong) tend to be heavier and have a higher pulp yield, while the husk has a thinner thickness. Greco et al. (2014) observed a strong correlation between fruit length and mass ( $\mathrm{rf}$ $=0.7353)$ and median correlation for length and $C / L$ ratio $(r f=0.6573)$ and found the acidity showed a median and negative correlation with ratio (SST/AT) and $\mathrm{pH}$. The negative correlations indicate that the selection based in one of the characteristics may have a high negative effect in the other aspect, which may be a problem in genetic breeding programs.

\section{Conclusions}

High heritability values in the broad sense and $\mathrm{CVg} / \mathrm{CVe}$ ratio were found for most of the characteristics studied, indicating favorable conditions for selection and the possibility of using simple selection methods, such as mass selection, for passion fruit genotypes. The genotypes of yellow passion fruit MAR20\#21 P2 x FB 200 P1 R2 and MAR20 \# 19 ROXO R4 x ECRAM P3 R3 showed the highest values for fruit mass and pulp mass with seed. The wild passion fruit cultivar BRS Mel do Cerrado showed the highest fruit mass among the wild ones. Most of the studied genotypes showed oval fruit shape, which is an interesting characteristic for the passion fruit industry.

Regarding the color parameters, the $L^{*}$ values ranged from 39.00 to 49.39 . The values of hue angle $\left(h^{*}\right)$, showed that the majority of the evaluated materials have orange color, except BRS Sertão Forte, which has a tendency to the yellow color.

All genotypes of wild, sweet and yellow passion fruit showed total soluble solids contents above the minimum required ( $11^{\circ}$ Brix) for the production of passion fruit pulp (Passiflora edulis Sims), according to the identity and quality standards of the Ministério da Agricultura, Pecuária e Abastecimento. The wild passion fruits of the genotypes CPAC MJ-02-17 and BRS Mel do Cerrado (Passiflora alata Curtis) reached values of total soluble solids of $16.11^{\circ}$ Brix and $18.46^{\circ}$ Brix, respectively. 
Positive and significant correlations were observed between the characteristics of CMP and MF, and MF and R: C/L ratio, demonstrating that oblong-shaped fruits tend to have higher fruit mass.

Authors' Contributions: NÓBREGA, D.N.: conception and design, acquisition of data, analysis and interpretation of data, drafting the article, and critical review of important intellectual content; MENDES, A.C.N.: acquisition of data, analysis and interpretation of data; PEIXOTO, J.R.: conception and design, analysis and interpretation of data, and critical review of important intellectual content; VILELA, M.S.: conception and design, analysis and interpretation of data, drafting the article, and critical review of important intellectual content; FALEIRO, F.G.: critical review of important intellectual content; ALENCAR, E.R.: acquisition of data, and critical review of important intellectual content; CARMONA, R.: critical review of important intellectual content; SOUSA, R.M.D.: critical review of important intellectual content.

Conflicts of Interest: The authors declare no conflicts of interest.

Ethics Approval: Not applicable.

Acknowledgments: The authors would like to thank the funding for the realization of this study provided by the Brazilian agencies CAPES (Coordenação de Aperfeiçoamento de Pessoal de Nível Superior - Brasil), Finance Code 001, and CNPq (Conselho Nacional de Desenvolvimento Científico e Tecnológico - Brasil). The authors would also like to thank Embrapa Cerrados and the Universidade de Brasília (UnB) for providing the necessary infrastructure for the study; and the workers of Fazenda Água Limpa and GeHorti/UnB (Horticulture Study Group/UnB) for their support in conducting the field study.

\section{References}

AGUIAR, R.S., et al. Produção e qualidade de frutos híbridos de maracujazeiro-amarelo no norte do Paraná. Revista Brasileira de Fruticultura. 2015, 37(1), 130-137. https://doi.org/10.1590/0100-2945-012/14

ALVES, R.R., et al. Relações entre características físicas e químicas de frutos de maracujazeiro-doce cultivado em Viçosa-MG. Revista Brasileira de Fruticultura. 2012, 34(2), 619-623. https://doi.org/10.1590/S0100-29452012000200038

BRASIL. Ministério da Agricultura, Pecuária e Abastecimento. 2106a. Formulário 3 - Espécies em regime de proteção: instruções de DHE e tabela de Descritores Mínimos. In: Frutíferas: Maracujá (Passiflora edulis Sims). Proteção de cultivares, Formulários para proteção de cultivares, Ministério da Agricultura, Pecuária e Abastecimento (MAPA). Disponível em: https://www.gov.br/agricultura/pt$\mathrm{br} /$ assuntos/insumos-agropecuarios/insumos-agricolas/protecao-de-cultivar/frutiferas

BRASIL. Ministério da Agricultura, Pecuária e Abastecimento. 2016b. Formulário 3 - Espécies em regime de proteção: instruções de DHE e tabela de Descritores Mínimos. In: Frutíferas: Maracujá (Passiflora L. e híbridos interespecíficos), exceto Passiflora edulis. Proteção de cultivares, Formulários para proteção de cultivares, Ministério da Agricultura, Pecuária e Abastecimento (MAPA). Disponível em: https://www.gov.br/agricultura/pt-br/assuntos/insumos-agropecuarios/insumos-agricolas/protecao-de-cultivar/frutiferas

BRASIL. Ministério da Agricultura. Instrução normativa no 37, de 1ㅇ de outubro de 2018. Diário Oficial da União, 08 de outubro, 2018. Disponível em: http://www.in.gov.br/materia/-/asset_publisher/Kujrw0TZC2Mb/content/id/44304943/do1-2018-10-08-instrucao-normativan-37-de-1-de-outubro-de-2018-44304612

CARDOSO, M.R.D., MARCUZZO, F.F.N., and BARROS, J.R. Classificação Climática de Köppen-Geiger para o Estado de Goiás e o Distrito Federal. Acta Geográfica (UFRR). 2014, 8(160), 40-55.

CARVALHO, F.I.F., LORENCETTI, C. and BENIN, G. Estimativas e implicações da correlação no melhoramento vegetal. Pelotas: Ed. Universitárias da UFPel, 2004.

CAVICHIOLI, J.C., CORRÊA, L.S., BOLIANI, A.C. and SANTOS, P.C. Características físicas e químicas de frutos de maracujazeiro-amarelo enxertado em três porta-enxertos. Revista Brasileira de Fruticultura. 2011, 33(3), 905-914. https://doi.org/10.1590/S0100-29452011000300026

CHAGAS, K., et al. Divergência genética em genótipos de maracujazeiro azedo, com base em características físicas e químicas dos frutos. Revista Ciência Agronômica. 2016, 47(3), 524-531.

COELHO, E.M., AZÊVEDO, L.C. and UMSZA-GUEZ, M.A. Fruto do maracujá: importância econômica e industrial, produção, subprodutos e prospecção tecnológica. Cadernos de Prospecção. 2016, 9(3), 347-361. http://doi.org/10.9771/cp.v9i3.16637

CRUZ, C.D. Programa Genes: aplicativo computacional em genética e estatística. Versão 1.0 [software]. Viçosa, MG: Editora UFV, 1997. [Acesso em 15 dezembro 2019]. Disponível em: http://arquivo.ufv.br/dbg/genes/Genes_EUA.htm

FARIAS, J.F., SILVA, L.J.B., ARAÚJO NETO, S.E. and MENDONÇA, V. Qualidade do maracujá-amarelo comercializado em Rio Branco, Acre. Revista Caatinga. 2007, 20(3), 196-202.

FERREIRA, M.D. and SPRICIGO, P.C., 2017. Parte 4. Análises não destrutivas: Capítulo 1. Colorimetria - Princípios e aplicações na agricultura. In: FERREIRA, M.D. Instrumentação pós-colheita em frutas e hortaliças. Brasília, DF: Embrapa, pp. 205-220.

FORTALEZA, J.M., et al. Características físicas e químicas em nove genótipos de maracujá-azedo cultivado sob três níveis de adubação potássica. Revista Brasileira de Fruticultura. 2005, 27(1), 124-127. http://dx.doi.org/10.1590/S0100-29452005000100033

GOMES, T.S., CHIBA, H.T., SIMIONATO, E.M.R.S. and SAMPAIO, A.C. Qualidade da polpa de maracujá amarelo - seleção afruvec, em função das condições de armazenamento dos frutos. Alimentos e Nutrição Araraquara. 2006, 17(4), 401-405. 
GRECO, S.M.L., PEIXOTO, J.R. and FERREIRA, L.M. Avaliação física, físico-química e estimativas de parâmetros genéticos de 32 genótipos de maracujazeiro azedo cultivados no Distrito Federal. Bioscience Journal. 2014, 30(supplement 1), 360-370.

IAL, INSTITUTO ADOLFO LUTZ. Métodos físico-químicos para análise de alimentos. 4ạ ed. digital. São Paulo: Instituto Adolfo Lutz, 2008.

JESUS, O.N., et al. Descritores morfoagronômicos ilustrados Passiflora spp. 1a ed. Brasília, DF: Embrapa, 2016.

JESUS, O.N., OLIVEIRA, E.J., SOARES, T.L. and FALEIRO, F.G. Aplicação de descritores morfoagronômicos utilizados em ensaio de DHE de cultivares de maracujazeiro-azedo (Passiflora edulis Sims): manual prático. 1a ed. Brasília, DF: Embrapa, 2015a.

JESUS, O.N., OLIVEIRA, E.J., SOARES, T.L. and FALEIRO, F.G. Aplicação de descritores morfoagronômicos utilizados em ensaio de DHE de cultivares de maracujazeiro-doce, ornamental, medicinal, incluindo espécies silvestres e híbridos interespecíficos (Passiflora spp.): manual prático. 1a ed. Brasília, DF: Embrapa, 2015b.

MACHADO, C.F., JESUS, F.N. and LEDO, C.A.S. Divergência genética de acessos de maracujá utilizando descritores quantitativos e qualitativos. Revista Brasileira de Fruticultura. 2015, 37(2), 442-449.

MARTINS, C.C., SILVA, N. and MACHADO, C.G. Testes para a seleção de populações de cenoura visando ao vigor e à longevidade das sementes. Ciência Rural. 2014, 44(5), 768-774.

MCGUIRE, R.G. Reporting of Objective Color Measurements. HortScience. 1992, 27(12), 1254-1255.

https://doi.org/10.21273/HORTSCI.27.12.1254

NEGREIROS, J.R.S., et al. Caracterização de frutos de progênies de meios-irmãos de maracujazeiro-amarelo em rio branco - Acre. Revista Brasileira de Fruticultura. 2008, 30(2), 431-437. https://doi.org/10.1590/S0100-29452008000200028

NETO, R.C.A., RIBEIRO, A.M.A.S., ALMEIDA, U.O. and NEGREIROS, J.R.S. Caracterização química, rendimento em polpa bruta e suco de diferentes genótipos de maracujazeiro azedo, 2015. Disponível em: https://www.embrapa.br/busca-de-publicacoes/-

/publicacao/1036536/caracterizacao-quimica-rendimento-em-polpa-bruta-e-suco-de-diferentes-genotipos-de-maracujazeiro-azedo

PATHARE, P.B., OPARA, U.L. and AL-SAID, F.A. Colour Measurement and Analysis in Fresh and Processed Foods: A Review. Food Bioprocess Technology. 2013, 6, 36-60. https://doi.org/10.1007/s11947-012-0867-9

RAIMUNDO, K., MAGRI, R.S., SIMIONATO, E.M.R.S. and SAMPAIO, A.C. Avaliação física e química da polpa de maracujá congelada comercializada na região de Bauru. Revista Brasileira de Fruticultura. 2009, 31(2), 539-543. https://doi.org/10.1590/S010029452009000200031

REOLON, A.A., BRAGA, G.C. and SALIBE, A.B. Características físico-químicas da casca do maracujá amarelo em diferentes estádios de maturação. Boletim Centro de Pesquisa de Processamento de Alimentos. 2009, 27(2), 305-312. http://dx.doi.org/10.5380/cep.v27i2.22041

SANTOS, V.A., et al. Produção e qualidade de frutos de maracujazeiro-amarelo provenientes do cultivo com mudas em diferentes idades. Revista de Ciências Agroveterinárias. 2017, 16(1), 33-40. https://doi.org/10.5965/223811711612017033

SHEWFELT, R.L., THAI, C.M. and DAVIS, J.W. Prediction of changes in color of tomatoes during ripening at different constant temperatures. Journal of Food Science. 1988, 53(5), 1433-1437. https://doi.org/10.1111/i.1365-2621.1988.tb09293.x

SILVA, M.S., ATAÍDE, E.M., SANTOS, A.K.E. and SOUZA, J.M.A. Qualidade de frutos de maracujazeiro amarelo produzidos na safra e entressafra no Vale do São Francisco. Revista Iberoamericana de Tecnología Postcosecha. 2016, 17(1), 41-49.

UNB. Universidade de Brasília. Base de Dados da Estação Meteorológica Automática (Dados diários). Fazenda Água Limpa/Universidade de Brasília - FAL/UnB, 2018 [visto em 10 de dezembro de 2018]. Disponível em: http://www.fav.unb.br/86-faculdade-veterinaria/128-base-dedados-estacao-automatica-dados-diarios

VIEIRA, J.V., CRUZ, C.D., NASCIMENTO, W.M. and MIRANDA, J.E.C. Seleção de progênies de meio-irmãos de cenoura baseada em características de sementes. Horticultura Brasileira. 2005, 23(1), 44-47. https://doi.org/10.1590/S0102-05362005000100009

Received: 15 October 2020 | Accepted: 4 April 2021 | Published: 28 October 2021

This is an Open Access article distributed under the terms of the Creative Commons Attribution License, which permits unrestricted use, distribution, and reproduction in any medium, provided the original work is properly cited. 